Magna Scientia Advanced Research and Reviews

eISSN: 2582-9394

Cross Ref DOI: $10.30574 / \mathrm{msarr}$

Journal homepage: https://magnascientiapub.com/journals/msarr/

Check for updates

(RESEARCH ARTiCle)

\title{
Effect of simulation and guided-inquiry strategies in elimination of students' misconception in biology teaching
}

\author{
Gideon Wokocha* \\ Faculty Education, Department of integrated Science Ignatius Aguru University of Education Rumuolumeni, Port Harcourt.
}

Magna Scientia Advanced Research and Reviews, 2021, 03(02), 009-016

Publication history: Received on 18 August 2021; revised on 05 November 2021; accepted on 07 November 2021

Article DOI: https://doi.org/10.30574/msarr.2021.3.2.0062

\begin{abstract}
This study investigates the effects of simulation and Guided-inquiry strategies in elimination of students' misconception in Biology Teaching in Senior Secondary Schools in Obio/Akpor Local Government Area in Rivers State. Four research questions and four hypotheses were formulated to guide the research. The design adopted for this study is quasi experimental pre-test, post-test control group design. The population of the study was made up of all SSIII biology students, using cluster sampling to select 150 students' to form the sample size. The research instrument used was Ecology performance Test (EPT). Mean and standard deviation were used to answer the research questions. T-test was used to test the hypotheses. The findings among others indicated that students taught with simulation and guided inquiry teaching strategy performed better than the traditional method thereby eliminating student's misconception on ecological concept in biology. It was recommended among others that biology teachers should be encouraged to explore the application of simulation and guided inquiring strategies in their classroom instruction.
\end{abstract}

Keywords: Simulation; Guided inquiry; Misconceptions; Biology teaching; Performance

\section{Introduction}

Today, we are all witnesses of the major breakthrough in scientific discoveries in the world. Science as a field of study has made it possible for man to know more about the universe. Science is a systematic study of natural phenomenon and its study allows students to experience the richness and excitement of the natural world as they engaged in inquiry, critical thinking and the demonstration of skills (Garuba, Agweda \& Avynebe 2012). The scientific enterprise is one that is challenging and innovative (Ajaja 2011).

In order to actualize our aspiration, we need nothing short of good performance of our science students at all levels of schooling. Alamina (2008) stated that the teaching of science must produce graduates who have practical exposure endowed with critical thinking and can express most of the scientific observations, theories and concepts using the most appropriate scientific language. The effective teaching and learning of science can lead to scientific literacy and attainment of scientific and technological greatness.

According to Ezendu (2013) Science Education has in many cases become teacher centered, based on rote memorization and focuses on test scores most students consider science to be boring, a list of big words and facts, intimidating and not relevant to their lives (Cimer, 2012). Science is also fostered as students experience no connection between their study and their real lives (Ajaja, 2011). Scientific literacy is more than just knowledge of scientific concepts, it is the ability to apply scientific knowledge to everyday problem-solving situation that impact health, safety and the environment. Education researchers have provided a deeper understanding of how students learn science. The process of moving students from their initial state of knowledge and understanding to a desired optimum level of learning has

\footnotetext{
* Corresponding author: Gideon Wokocha

Faculty Education, Department of integrated Science Ignatius Aguru University of Education Rumuolumeni, Port Harcourt.

Copyright (c) 2021 Author(s) retain the copyright of this article. This article is published under the terms of the Creative Commons Attribution Liscense 4.0.
} 
been the focus of the teaching profession worldwide. One major product of teacher-learner interaction is misconception. Alamina (2018) defines misconception as student personal understandings which differ from universally accepted scientific knowledge. She stated that students lack scientific understanding of basic science concepts, students utilize scientific concepts and explanations inappropriately, showing disjuncture scientific reasoning which reveals lack of understanding of the science concepts being tested, resulting in misconceptions which often have different meaning from correct conceptions held by scientists.

Students have plenty of misconception due to insufficient understanding of ideas. This may arise due to unsatisfactory explanation or confusion in comprehension due to lack of attention-students need to be made aware off, as clearer concepts as possible. This will help curtail students going further in biology with consistent picture as possible. Several studies have shown that it is difficult to eliminate misconceptions (Gnegg, Winer, Cottrell, Hedman \& Fournien, 2001; Landau \& Bavaria, 2003 in Hughes \& Luddy, 2013). Misconception stands as an obstacle to learning and these obstacles need to be abandoned or weakened before a new conception can develop. They ascertained that teaching strategies should be adopted. This means that misconception can be corrected by raising or restructuring currently held inaccurate beliefs. Successful learning will results only when students critically evaluate previously held beliefs as well as revise and replace them with new consistent information. Since students poor knowledge is one way you can identify and eliminate misconception.

Ogunkola and Samuel (2011) added that the key factors in facilitating an effective learning environment in the science class are the teaching strategies used by the teachers. Also the achievement and failure of students depends on the teachers teaching style. Some of the methods used by the teachers are didactic and students become very passive. To make teaching and learning of biology effective, innovative teaching strategies should be adopted. The researcher believes that simulation learning and guided inquiry strategies may ensure a purposeful (result oriented biology concepts delivery in schools).

Simulation learning can be described as a simplification of some real life situations and it is a learning method in which learners are confronted with what can be regarded as an approximation of a real life situation; it consists of role play, games and model. (Perry et al, 2009). According to Obeka (2007) Simulation means to imitate something or someone. It is the product that results when one creates the appearance or effect of something else.

Simulation is a form of experiential learning. It is a strategy that fits well with the principles of student-centred learning. In many respects, a simulation is a model of the real world, in which the participants have specific roles to play, make decisions and solve problems according to specified condition (Akinsola and Animashun, 2007). Simulation methods are activities or materials that represent real life situations past events in such a way that students learn and understand more about them. This means that simulation possesses a high degree of similarity with reality. Also according to Ekwe (2013), simulation method of teaching has the ability to improve students' performance and attitude towards biology.

Guided inquiry is inquiry guided by an instructional team to enable students gain an depth of understanding and a personal perspective through a wide range of sources of information (Kuhlthau, Maniotes, \& Gaspan, 2007). It is planned targeted supervised intervention. Guided inquiry involves students in every stage of learning using a variety of sources under the guidance of the teacher. The teacher provides materials and problems to investigate, students device their own procedure in solving the problems. It is students' centered-activity oriented teaching strategy. The teacher guides the students to discover answers to a problem. The teacher may even explain or give clue or procedure in solving the problem (Perry et al, 2009).

Wokocha (2019) stated that in inquiry exercise, the learner puts things together for himself so that he becomes his own discover. The teacher acts as a catalyst rather than a dispenser of information. He offers students problem issue, questions and then provides encouragement for inquiry into the nature of the problems and guidance for seeking solution. According to Akuma (2007), this method helps to increase the degree of student's interest, confidence innovativeness, and problem-solving ability and consequently improve their performance in both theory and practice.

\subsection{Statement of the Problem}

The growing number of failures in Biology in WAEC Examinations is of great concern. There have been reports of poor performance of candidates in biology by WAEC Chief Examiners (Umeh, 2006). This points to the fact that the learners are not getting adequate knowledge, understanding and skills in Biology. The students have a lot of misconception about science (Alamina 2018). The poor academic achievement of students in biology raises dust on the efficacy of the teaching approaches utilized by teachers. Students have insufficient understanding of ideas about biology concepts and this may arise due to unsatisfactory explanation or confusion of the teaching strategy being employed by the teacher. It is 
pertinent to investigate the efficacy of innovative teaching strategies on elimination of misconceptions. The researcher intends to investigate the effects of simulation and guided inquiry strategies on elimination of students' misconceptions in biology teaching and learning in senior secondary schools in Obio/Akpor in Rivers State. The question the researcher seeks to answer is: What will be the effects of simulation and guided inquiry strategies on elimination of students' misconception in biology against the conventional method?

\subsection{Purpose of the Study}

In general terms, the purpose of this study is to find out the effects of simulation and guide-inquiry strategies in elimination of misconceptions in Biology in senior secondary schools in Rivers State. Specifically, the study seeks to:

- Determine the effect of simulation teaching strategy in elimination of students' misconception in some selected concept in ecology.

- Determine the effect of guided-inquiry strategy in elimination of students' misconception in some concept in ecology.

- Determine the effect of traditional method in elimination of students' misconception in some concept in biology.

Compare the effects of stimulation and guided-inquiry strategies in elimination of students' misconception in some concept in ecology.

\subsection{Research Questions}

The study will provide answers to the following research questions:

- What are the effects of simulation teaching strategy in elimination of students' misconception in some selected concept in ecology?

- What are the effects of guided-inquiry teaching strategy in elimination of students' misconception in some selected concept in ecology?

- What are the effects of traditional method in elimination of students' misconception in some selected concept in biology?

- How does the effect of simulation and guided-inquiry strategies eliminate students' misconception in some selected concept in ecology against the traditional method?

\subsection{Research Hypotheses}

The following (null) hypotheses were formulated and tested for the study:

- There is no significant effect of simulation teaching strategy on elimination of students' misconception in ecology.

- There is no significant effect of guided inquiry teaching strategy in elimination of student's misconception in ecology.

- There is no significant effect of traditional teaching method on elimination of students' misconception in some selected concept in biology.

- There is no significant difference in the post-test mean scores of students taught ecology using simulation and guided inquiry strategies against the traditional method.

\subsection{Research design}

The design of this study is quasi-experimental. Specifically, it used pretest, post-test control group to determine the effects of simulation guided inquiry strategies in elimination of students misconception in biology in senior secondary school in Rivers State.

\section{Area of study}

The study was conducted in senior secondary schools in Obio/Akpor Local Government area of Rivers State. 


\subsection{Population of the study}

The population of this study consisted of all the Senior Secondary School III Biology students in all public secondary schools in Obio/Akpor Local Government Area of Rivers State in the 2018/2019 academic session made the population.

\subsection{Sampling/Sampling technique}

Cluster sampling technique was used to select two schools for the experimental and control group. Two intact classes were randomly selected from one arm of the SS3 from each school. A sample of 150 senior secondary (SS3) biology students was used for the study with 75 students in each of the classes.

\subsection{Research Instrument}

The research instrument used to collect data for the study was Ecology Performance Test (EPT). However, a 30-item multiple choice objective test with four options developed by the researcher was used.

\subsection{Validation}

The test instruments used in the study were validated by two persons: a Biology teacher from the selected schools and also a Biology Education lecturer at Ignatius Ajuru University of Education, Rumuolumeni, so as to meet both face and content validation.

\subsection{Method of Data Collection}

Students in the experimental group were taught ecology concept with simulation and guided inquiry strategies while students in control group were taught with traditional methods. Post-test scores were collected after four weeks of treatment.

\subsection{Method of Data Analysis}

The scores obtained from the pre-test and post test were analyzed using mean and standard deviation to answer the research questions while T-test was used to test the hypotheses for significant difference at 0.05 level.

\section{Results}

Results of data analysis were presented in tables accordingly.

Research question 1: What are the effects of simulation teaching strategy in elimination of student misconception on the concept of ecology. This research question was answered using mean and standard deviation which were computed for the pre-test and post -test scored of the students taught with simulation teaching strategy.

Table 1 Mean pre-test and post-test scores of students taught with simulation teaching strategy

\begin{tabular}{l|c|c|c|}
\hline & Pre-test & Post-test & Mean gain \\
\hline Mean $(\bar{x})$ & 28.27 & 69.10 & 40.83 \\
\hline N & 150 & 150 & \\
\hline SD & 9.42 & 48.52 & \\
\hline
\end{tabular}

The result in Table1 shows the mean score of the students pre-test as 28.27 with standard deviation of 9.42, while posttest of 69.10, with standard deviation of 48.52. This indicates that the student performed better in the post test than in the pretest. Simulation teaching strategy has positive effective in elimination of students' misconception with improvement in their mean performance.

Research Question 2: What are the effects of guided inquiry teaching strategy in elimination of student misconception on the concept of ecology? 
Table 2 Mean pre-test and post-test scores of Guided inquiry teaching strategy

\begin{tabular}{l|ccc|}
\hline & Pre-test & Post-test & Mean gain \\
\hline Mean $(\bar{x})$ & 23.77 & 52.50 & 28.77 \\
\hline N & 150 & 150 & \\
\hline SD & 6.39 & 10.21 & \\
\hline
\end{tabular}

The result shows that the mean scores of the students pre-test is 2377 with standard deviation of 6.39 , while post test scores is 52.50 with standard deviation of 10.21 . This indicates that the students performed better in the post-test than in their pre-test. Guided inquiry teaching strategy has positive effect on elimination of student misconception in ecology with improvement in their mean performance scores.

Research Question 3: What are the effects of traditional teaching strategy in elimination of student misconception on the concept of ecology?

\begin{tabular}{l|ccc|}
\hline & Pre-test & Post-test & Mean gain \\
\hline Mean $(\bar{x})$ & 15.5 & 21.8 & 6.5 \\
\hline N & 150 & & \\
\hline SD & 25 & 2.6 & \\
\hline
\end{tabular}

Table 4.1.3 shows the mean score for the traditional teaching strategy. The pretest is 15.5 while the post-test is 21.8 with a mean gain of 6.5 , indicating a positive effect.

Research Question 4: How does the effect of simulation and guide inquiry teaching strategy eliminate student's misconception on the concept of ecology against the traditional method?

Table 4 Mean pre-test post-test score of teaching methods

\begin{tabular}{|l|c|c|c|}
\hline \multicolumn{1}{|c|}{ Methods } & Pre-test & post-test & mean gain \\
\hline Simulation & 28.27 & 69.10 & 40.83 \\
\hline Guide inquiry & 23.77 & 52.50 & 28.77 \\
\hline Lecture & 15.5 & 21.8 & 6.3 \\
\hline
\end{tabular}

Table 4 shows that the posttest means scores of simulation learning, guided inquiry strategy and traditional teaching method were higher than the pre-test mean scores of 69.10 with a mean gain of 40.83 . Guided inquiry has post test of 52.50 with a mean gain 28.77 while the traditional method has a post test score of 21.8 with a mean gain of 6.3 .

Hypothesis 1 There is no significant effect of simulation teaching strategy in elimination of student's misconception on concept of ecology.

This null hypothesis shows that the calculation t-value is 11.72 which is greater than the critical t-value of 2.042 at 69 degrees of freedom at 0.05 level of significance. Since the calculated value is higher, the null hypothesis is rejected. This indicates a significant effect of simulation strategy in elimination of student's misconception on ecology concepts. 
Table 5 T-test analysis on the mean effect of simulation strategy on the concept of ecology

\begin{tabular}{|l|c|c|c|c|c|c|}
\hline & Mean & SD & N & df & t-cal & t-crit \\
\hline Pre-test & 26.27 & 4.42 & 150 & \multirow{2}{*}{138} & \multirow{2}{*}{11.92} & 2.042 \\
\cline { 1 - 5 } Post -test & 69.10 & 48.52 & 150 & & & \\
\hline
\end{tabular}

Hypothesis 2: There is no significant effect of Guided inquiry teaching strategy in elimination of student's misconception in ecology concept.

Table 6 T-test analysis on the mean effect of Guided inquiry strategy on the concept of ecology

\begin{tabular}{|c|c|c|c|c|c|c|}
\hline & Mean & SD & N & df & t-cal & t-crit \\
\hline Pre-test & 23.77 & 6.39 & 150 & \multirow{2}{*}{138} & \multirow{2}{*}{43.03} & 2.042 \\
\cline { 1 - 5 } Post -test & 52.50 & 1021 & 150 & & & \\
\hline
\end{tabular}

The table 6 shows the calculation value as 43.03 while the critical t-value is 2.042 at degree of freedom at 0.05 level of significant. Since the calculated value is higher, the null hypothesis is rejected. This indicates a significant effect of guided inquiry teaching strategy in elimination of misconception of ecology concept.

Hypothesis 3: There is no significant effect of traditional method in elimination of student's misconception on ecology concept.

Table 7 T-test analysis on the mean effect of traditional method on ecology concept

\begin{tabular}{|c|l|c|c|c|c|c|}
\hline & Mean & SD & N & df & t-cal & t-crit \\
\cline { 1 - 5 } Pre-test & 15.5 & 2.5 & 150 & \multirow{2}{*}{138} & \multirow{2}{*}{0.2359} & \multirow{2}{*}{1.980} \\
\cline { 1 - 5 } Post -test & 21.8 & 2.6 & 150 & & & \\
\hline
\end{tabular}

The table 3 shows the calculated value as 0.2359 is less than the critical value of $t 1.980$ at 0.05 level of significant. Therefore the null hypothesis under investigation is accepted. That is students who are taught with traditional method do not differ in the level of their performance when subjected to the pre-test method when taught ecology.

Hypothesis 4: There is no significant difference in the post-test mean of students taught ecology using simulation and guided inquiry strategies in elimination of misconception against the traditional method.

Table $8 \mathrm{~T}$-test analysis of post test mean performance of students taught using simulation and guided inquiry strategy against traditional method

\begin{tabular}{|l|c|c|c|c|c|c|}
\hline Groups (post-test) mean & $\mathbf{( x )}$ & SD & N & df & t-cal & t-crit \\
\hline Simulation & 69.10 & 48.52 & 150 & & & \\
\cline { 1 - 5 } Guided inquiry & 52.50 & 10.21 & 150 & \multirow{2}{*}{138} & \multirow{2}{*}{11.92} & 2.042 \\
\cline { 1 - 5 } Traditional method & 21.8 & 2.6 & 150 & & & \\
\hline
\end{tabular}

From table 8 since the calculated value (11.92) is greater than the critical value 2.04 at 0.05 significant, the null hypothesis is rejected. This implies that there is a significant difference between the mean performances of students taught using simulation and guided inquiry teaching strategy with respect to understanding of the ecology concept in elimination of student's misconception of ecology concept. 


\section{Discussion of Findings}

The discussion of the result of this study showed that simulation and guided inquiry teaching strategies enhance students' understanding of ecology concept. This implied that using simulation and guided inquiry teaching strategies as instructional methods have more positive effect in facilitating student understanding of the concept of ecology than the traditional method. The results of this study were in line with the views of previous researcher like Ekwe (2013) in his views, simulation in the classroom creates a situation in which students work with the ideas that are being taught and also applied them effectively.

Also Akuma (2007) revealed that guided inquiry helped to increase the degree of students' interest, confidence innovativeness, and problem-solving ability and consequently improve their understanding of science concepts easier and learning with less difficulty thereby increasing their performance in both theory and practice. This is because students are motivated to learn and this might be as a result of kin interest of opportunity to interact with the teacher and also to ask questions in a friendly environment gives rise to more meaningful and effective learning.

\section{Conclusion}

Based on the findings the following conclusions were drawn. Teaching strategy from reviews has the potential to make or mar student's misconception. Students had a lot of misconception before their exposure to simulation and guided inquiring learning strategy. Both strategies have effect on elimination of misconceptions of ecological concepts.

\section{Recommendations}

On the basis of findings from this study, it is recommended that:

- Biology teachers should be encouraged to explore the application of simulation and guided inquiry strategy in their classroom instruction in helping them in skill development.

- Teacher training institutions (university and college of Education should be trained on the use of these innovative strategies in order to integrate it in there instructional delivery.

- Seminars and workshops should be organized for serving teachers to keep abreast with new innovative strategies in teaching biology at the senior secondary school level.

- More time should be allotted to biology in the school timetable to allow the use of simulation and inquiry strategies as these strategies takes more time.

\section{Compliance with ethical standards}

\section{Acknowledgments}

The ICT department of IUAE is well acknowledged for providing the necessary conditions for the study.

\section{References}

[1] Alamina JL. Exploiting Misconception towards Optimum Teaching and Learning. Inaugural Lecture, Rivers State University, Series. 2018; 55.

[2] Ajaja P. Concept Mapping as study Skill: Effects on Students Achievement in Biology. International Journal of Education Science. 2011; 3 (1): 49-57.

[3] Alamina JI. Foundational Principles of Science Teaching and Learning. Port Harcourt: Votex Publishers. 2008.

[4] Akinsola MK, Animashun IA. The Effects of Simulation-Games Environment on Students' Achievement and Attitudes toward Mathematics in Secondary Schools. The Thurkish Online Journal of Educational Technology, July 2007. 6(3): 11.

[5] Akuma N. Effect of Guided Inquiry Method on Senior Secondary School Students Achievement in Map Work Journal of WCCI. 2007; 5(2):185-194.

[6] Ezeudu FO. Influence of Concept Maps on Achievement Retention of Senior Secondary School Students in Organic Chemistry Journal of Education and Practice. 2013; 4(99): 35-40. 
[7] Ekwe AI. Effects of Simulation and Project Methods on Academic Performance of Students in Ikwerre Local Government Area of Rivers State. M.Sc Thesis, Department of Curriculum Studies and Educational Technology, Faculty of Education, University of Port Harcourt. 2013.

[8] Garuba MA, Agweda FE, Abumene D. The Contribution of Science and Technology to National Development. Journal of Education and Practice. 2012; 3(1): 23-28.

[9] Gregg VR, Winer GA, JE, Hed-man, K.E, Fouurnier JS. The Persistence of a Misconception about Osu after Educational Intervention Psychonomic Bulletin. 2001; 8: 622-626.

[10] Hughes S, Lyddy F. Misconceptions about Psychological Science. 2013.

[11] Kuhithau C, Maniotes H, Caspari A. Guided Inquiry Learning in the 21st Century. 2007.

[12] Obeka SS. Comparative Effect of Epodewald and Power Simulation Games on Students Achievement and Interest in Some Environmental Education Concepts in Geography. Unpublished Ph.D thesis. Nsukka. University of Nigeria. 2007.

[13] Ogunkola BJ, Samuel D. Science Teachers and Students Perceived Difficult Topics in the Integrated Science Curriculum of Lower Secondary Schools in Babardos. World Journal of Education. 2011.; 1(2): 17-29.

[14] Perry WG. Jr. Forms of Intellectual and Ethical Development in College Years. A Scheme. New York, Holt, Reinhart.1970.

[15] Wokocha GA. Biology Made Easy and Science Education for Schools and Colleges. Omoku, Nigeria: Chicom Graphic. 2017. 